\title{
Pemanfaatan Metode Activity Based Costing Dalam Sistem Informasi Akuntansi Penentuan Biaya Pada Bengkel Muji Jaya
}

\author{
Sukemi Kamto Sudibyo ${ }^{1}$, Fitri Puji Astuti² \\ 1Universitas STEKOM \\ Jl.Majapahit 605, e-mail: sukemi@stekom.ac.id \\ 2 Universitas STEKOM \\ Jl.Majapahit 605, e-mail: fitripujiastuti15@gmail.com
}

\section{ARTICLE INFO}

Article history:

Received 30 September 2021

Received in revised form 2 Oktober 2021

Accepted 12 Oktober 2021

Available online 29 Oktober 2021

\begin{abstract}
The Muji Jaya Workshop in determining the cost of body repair, it still uses a manual estimate model with paper media which will result in losses if the calculation of the cost of body repair that is informed to the customer is not enough so that the body repair costs received are not sufficient for the needs of raw material costs and labor costs in body work. The repair and preparation of financial statements will be disrupted and delayed for a long time if the note paper used is lost or damaged. This results in the owner not being able to make decisions quickly, precisely and accurately.

From these various problems, Workshop Muji Jaya implements the use of the activity based costing method in the accounting information system for determining body repair costs in order to make it easier to determine the cost of body repairs to be more accurate and in presenting financial statements to be easier and more efficient because this method is guided by the assignment of costs to products. or services based on all required activities.
\end{abstract}

Keywords: estimation, cost, activity based costing

\begin{abstract}
Abstrak
Bengkel Muji Jaya dalam penentuan biaya body repair masih menggunakan model taksiran manual dengan media kertas yang akan berakibat kerugian apabila perhitungan biaya body repair yang diinformasikan kepada customer kurang sehingga biaya body repair yang diterima tidak mencukupi kebutuhan biaya bahan baku dan biaya tenaga kerja dalam pengerjaan body repair tersebut dan penyusunan laporan keuangan menjadi terganggu dan terhambat lama apabila kertas catatan yang digunakan hilang atau rusak. Hal ini mengakibatkan pemilik tidak dapat mengambil keputusan secara cepat, tepat dan akurat.

Dari berbagai permasalahan tersebut, maka Bengkel Muji Jaya mengimplementasikan pemanfaatan metode activity based costing dalam sistem informasi akuntansi penentuan biaya body repair
\end{abstract}


guna mempermudah penentuan biaya body repair menjadi lebih akurat dan dalam penyajian laporan keuangan menjadi lebih mudah dan efisien karena metode ini berpedoman pembebanan biaya ke produk atau jasa berdasarkan semua aktivitas yang diperlukan.

Kata kunci : taksiran, biaya, activity based costing

\section{PENDAHULUAN}

Bengkel Muji Jaya merupakan sebuah badan usaha dibidang jasa body repair mobil. Pada Bengkel tersebut dalam penentuan biaya body repair kepada konsumen masih menggunakan model taksiran manual dengan media kertas. Dengan model taksiran manual tersebut akan berakibat kerugian apabila perhitungan biaya body repair yang diinformasikan kepada custumer kurang sehingga biaya body repair yang diterima tidak mencukupi kebutuhan biaya bahan baku dan biaya tenaga kerja dalam pengerjaan body repair tersebut. Perhitungan biaya body repair pada bengkel tersebut hanya dihitung berdasarkan biaya bahan baku dan biaya tenaga kerja yang diperlukan.

Jenis biaya bahan baku dan biaya tenaga kerja harus ditentukan dengan cermat dalam pencatatan maupun penggolongan sehingga perhitungan biaya body repair dan laba yang dihasilkan dapat diandalkan. Bengkel Muji Jaya seharusnya mengimplementasikan pemanfatan metode Activity Based Costing dalam penentuan biaya body repair karena metode ini berpedoman pembebanan biaya ke produk atau jasa berdasarkan semua aktivitas yang diperlukan. Belum adanya sistem informasi penentuan biaya body repair pada Bengkel Muji Jaya juga mengakibatkan penyusunan laporan keuangan menjadi terganggu dan terhambat lama apabila kertas catatan yang digunakan hilang atau rusak. Hal ini mengakibatkan pemilik tidak dapat mengambil keputusan secara cepat, tepat dan akurat.

Dari berbagai permasalahan diatas, maka Bengkel Muji Jaya perlu mengimplementasikan sistem informasi akuntansi penentuan biaya body repair menggunakan metode activity based costing. Sistem informasi tersebut untuk mempermudah penentuan biaya body repair menjadi lebih akurat sebab penentuan biaya dihitung berdasarkan semua aktivitas dan dalam penyajian laporan keuangan menjadi lebih mudah dan efisien.

\section{Identifikasi Masalah}

1) Penentuan biaya body repair kepada konsumen masih menggunakan model taksiran manual dengan media kertas yang dapat mempengaruhi pada ketidaktepatan penentuan biaya body repair. Media kertas yang digunakan bisa hilang atau mengalami kerusakan yang berdampak pada kinerja penyusunan laporan keuangan menjadi terganggu dan terhambat lama yang mengakibatkan pemilik tidak dapat mengambil keputusan secara cepat, tepat dan akurat.

2) Penentuan biaya body repair belum menerapkan metode activity based costing yaitu metode yang berpedoman pada pembebanan biaya ke produk atau jasa dicatat berdasarkan semua aktivitas yang diperlukan.

\section{TINJAUAN LITERATUR}

\subsection{Sistem Informasi Akuntansi}

Sistem informasi akuntansi merupakan sistem yang menyediakan informasi akuntansi dan keuangan beserta informasi lainnya yang diperoleh dari proses rutin transaksi akuntansi. [5]

Sistem informasi akuntansi adalah bagian dari akuntansi yang berhubungan dengan penyusunan sistem akuntansi sebuah perusahaan sehingga diperoleh informasi yang lebih cepat dan lebih akurat dengan biaya yang termurah. [3]

\subsection{Activity Based Costing}

Activity Based Costing adalah sistem akuntansi yang berfokus pada aktivitas-aktivitas yang dilakukan untuk menghasilkan produk atau jasa. Aktivitas (activity) adalah setiap kejadian atau transaksi yang merupakan pemicu biaya (cost driver) yakni bertindak sebagai faktor penyebab (causal factory) dalam pengeluaran biaya dalam organisasi. [1]

Dalam metode activity based costing diketahui parameter-parameter yang digunakan dalam mencari atau menghitung biaya pokok produksi per unit produk, adapun parameternya antara lain : biaya bahan 
baku yang digunakan dalam proses produksi, biaya tenaga kerja langsung yang terlibat dalam proses produksi, dan biaya overhead yang dibebankan pada proses produksi. [4]

\section{PERANCANGAN SISTEM INFORMASI}

\subsection{Perancangan Sistem}

Berikut ini merupakan desain diagram context pemanfaatan metode Activity Based Costing dalam sistem informasi akuntansi penentuan biaya pada Bengkel Muji Jaya.

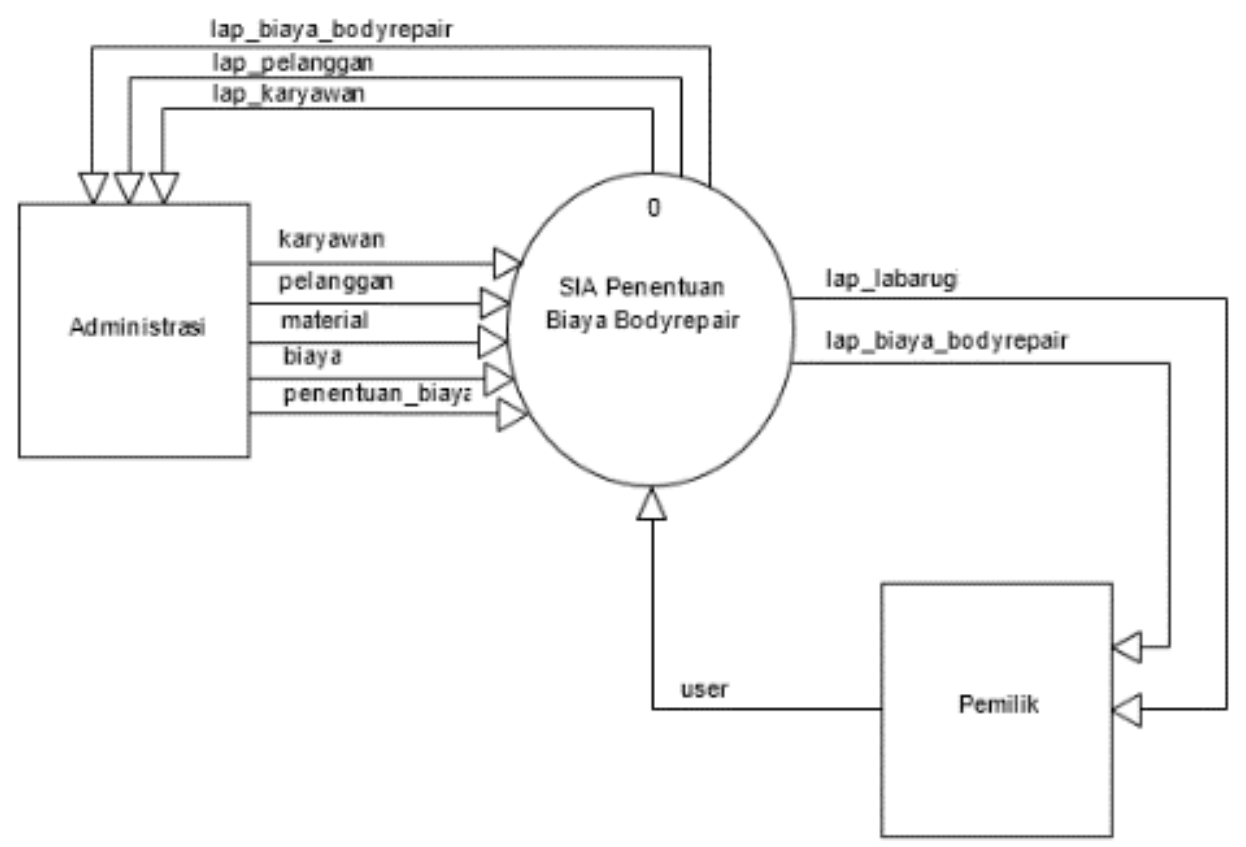

Gambar 1. Diagram Konteks

Pada diagram context diatas menunjukan tentang pemanfaatan metode Activity Based Costing dalam sistem informasi akuntansi penentuan biaya pada Bengkel Muji Jaya, unit yang terkait dalam sistem tersebut yaitu Administrasi dan Pemilik.

\subsection{Normalisasi}

Normalisasi adalah suatu teknik yang membuat tabel dengan struktur yang baik dengan cara-cara tertentu untuk membantu atau mencegah timbulnya masalah yang berhubungan dengan pengolahan data dalam basis data. [2] 
191

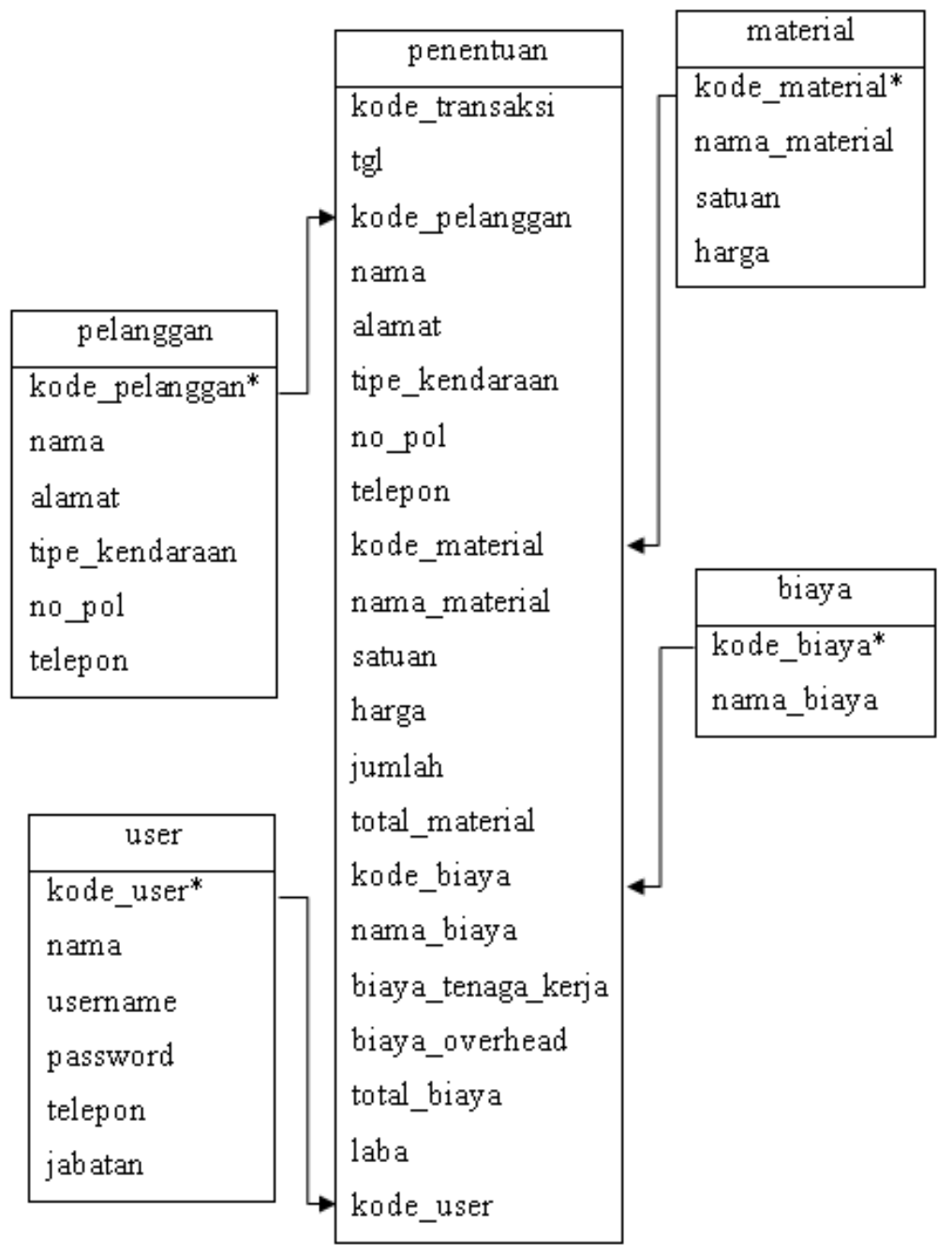

Gambar 2. Normalisasi 
4. HASIL PENELITIAN

Berikut merupakan tampilan dari pemanfaatan metode Activity Based Costing dalam sistem informasi akuntansi penentuan biaya pada Bengkel Muji Jaya :

\subsection{Form Login}

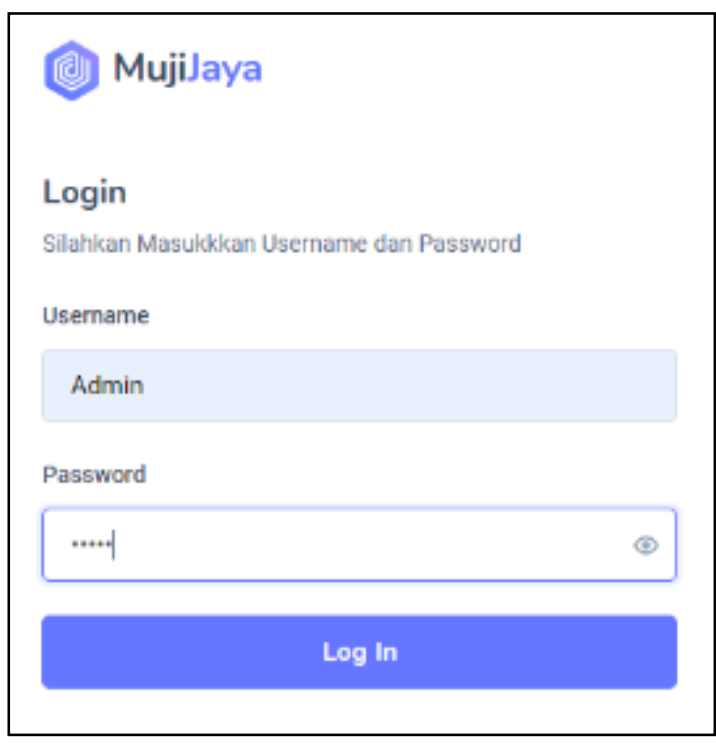

Gambar 3. Form Login

Masuk ke sistem, user harus login terlebih dahulu dengan input username dan password dengan benar.

\subsection{Halaman Utama}

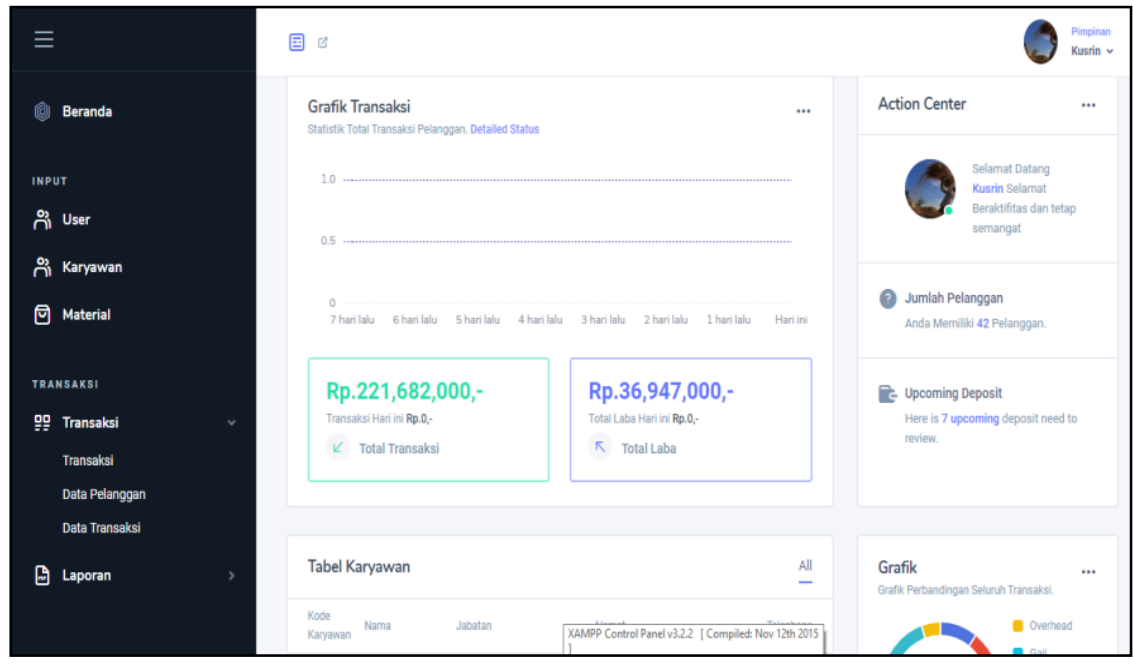

Gambar 4. Halaman Utama

JURNAL ILMIAH MANAJEMEN DAN KEWIRAUSAHAAN Vol.1, No.2, Oktober 2021, pp. 188 - 197 


\section{Keterangan :}

1. Data
a. User
mengelola user
b. Karyawan
mengelola karyawan
c. Material
mengelola material
d. Pelanggan
mengelola pelanggan
penentuan biaya body repair

2. Transaksi

3. Laporan
a. Laporan Pelanggan
menampilkan laporan
pelanggan
b. Laporan Karyawan
menampilkan laporan karyawan
c. Laporan Penentuan Biaya
menampilkan laporan penentuan biaya body
repair
d. Laporan Laba
menampilkan laporan laba

\subsection{Form User}

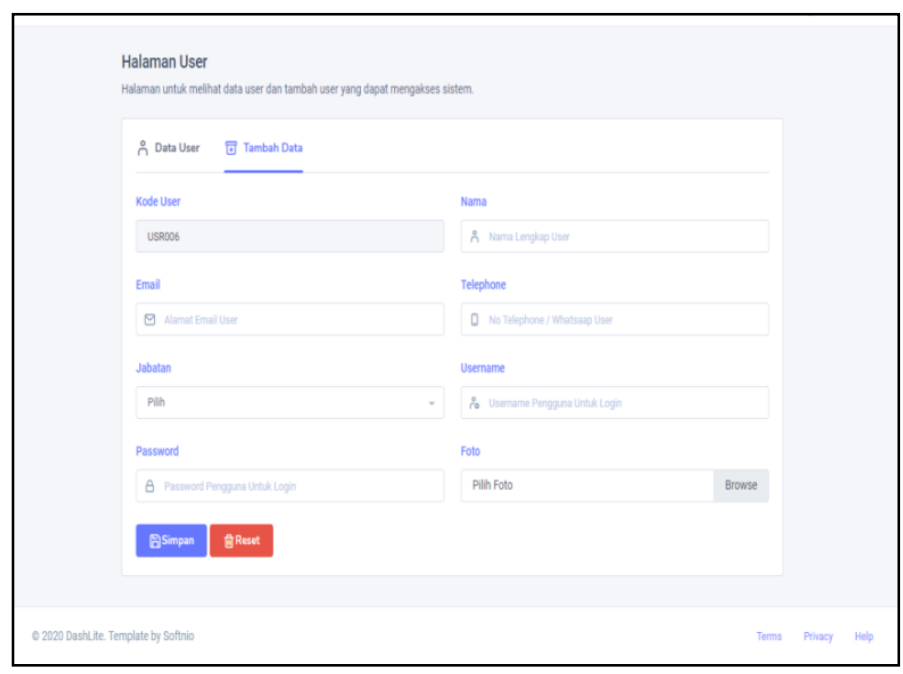

Gambar 5. Form User

\section{Keterangan :}

1. Textbox Kode User

2. Combobox Jabatan

3. Textbox Password

4. Textbox Nama

5. Texbox Telepon

6. Textbox Username

7. Browse

8. Simpan

9. Reset

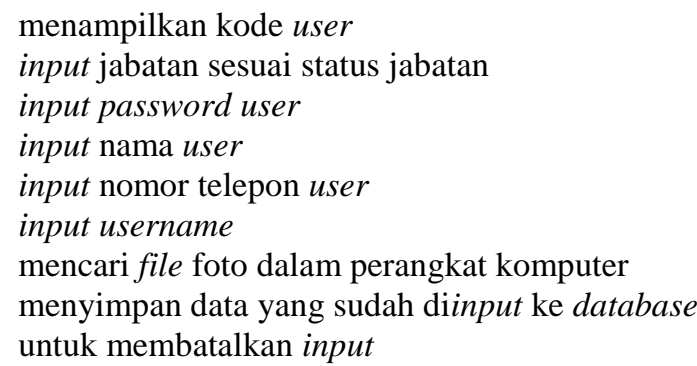


4.4 Form Karyawan

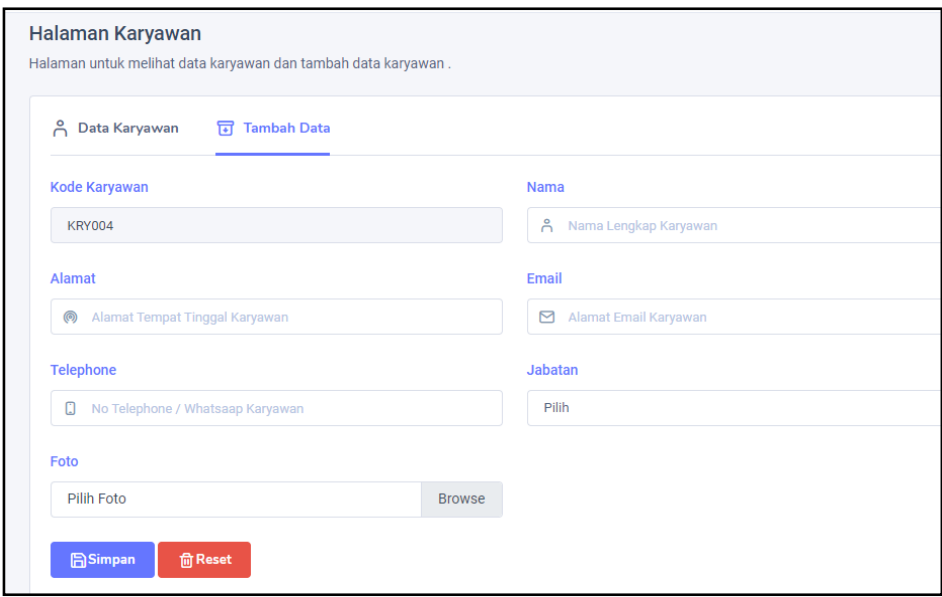

Gambar 6. Form Karyawan

\section{Keterangan :}

1. Textbox Kode Karyawan

2. Textbox Alamat

3. Textbox Telepon

4. Browse

5. Textbox Nama

6. Combobox Jabatan

7. Simpan

8. Reset

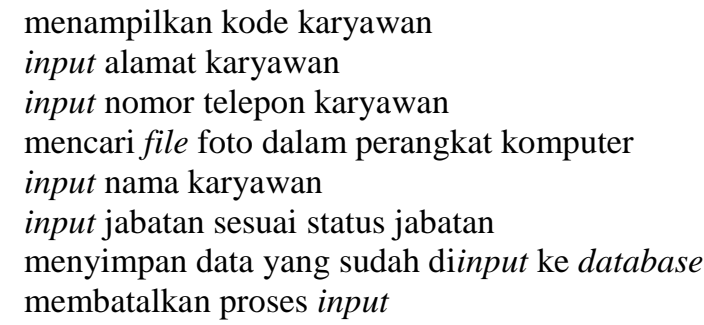

\subsection{Form Material}

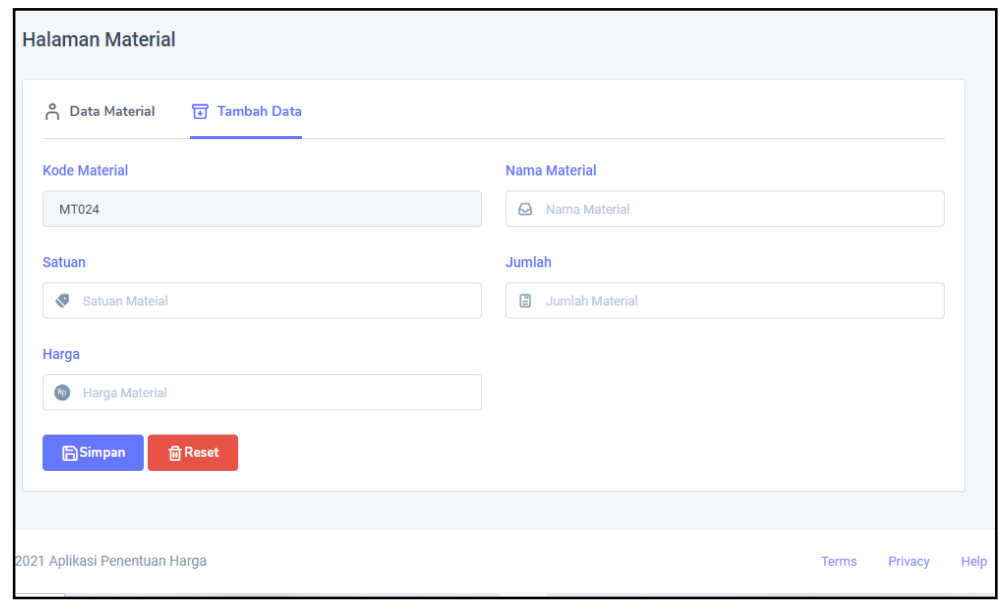

Gambar 7. Form Material 


\section{Keterangan :}

1. Textbox Kode Material

2. Textbox Satuan

3. Textbox Harga

4. Textbox Nama

5. Textbox Jumlah

6. Simpan

7. Reset menampilkan kode material

input satuan material

input harga material

input nama material

input jumlah material

menyimpan data yang sudah diinput ke database

membatalkan proses input

\subsection{Form Penentuan Biaya}

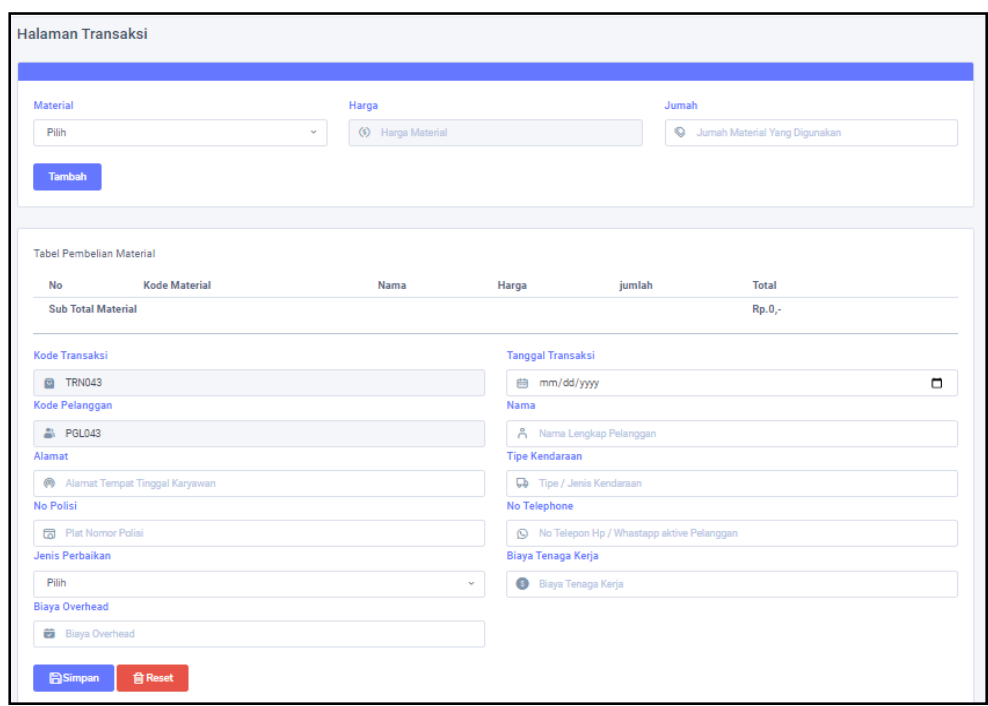

Gambar 8. Form Penentuan Biaya

\section{Keterangan :}

1. Combobox Material

2. Textbox Harga

3. Textbox Jumlah

4. Textbox Kode Transaksi

5. Textbox Kode Pelanggan

6. Textbox Alamat

7. Textbox No Polisi

8. Combobox Jenis Perbaikan

9. Textbox Biaya Overhead

10. Textbox Tanggal Transaksi

11. Textbox Nama

12. Textbox Tipe Kendaraan

13. Textbox Telepon

14. Textbox Biaya Tenaga Kerja

15. Simpan

16. Reset input data pilihan material menampilkan harga material input jumlah material yang dibutuhkan menampilkan kode transaksi menampilkan kode pelanggan input alamat pelanggan input no polisi pelanggan input jenis perbaikan sesuai kerusakan yaitu ringan, sedang dan berat input biaya overhead input tanggal transaksi input nama pelanggan input tipe kendaraan pelanggan input nomor telepon pelanggan input biaya tenaga kerja menyimpan data yang sudah diinput ke database

membatalkan proses input 


\subsection{Nota Penentuan Biaya}

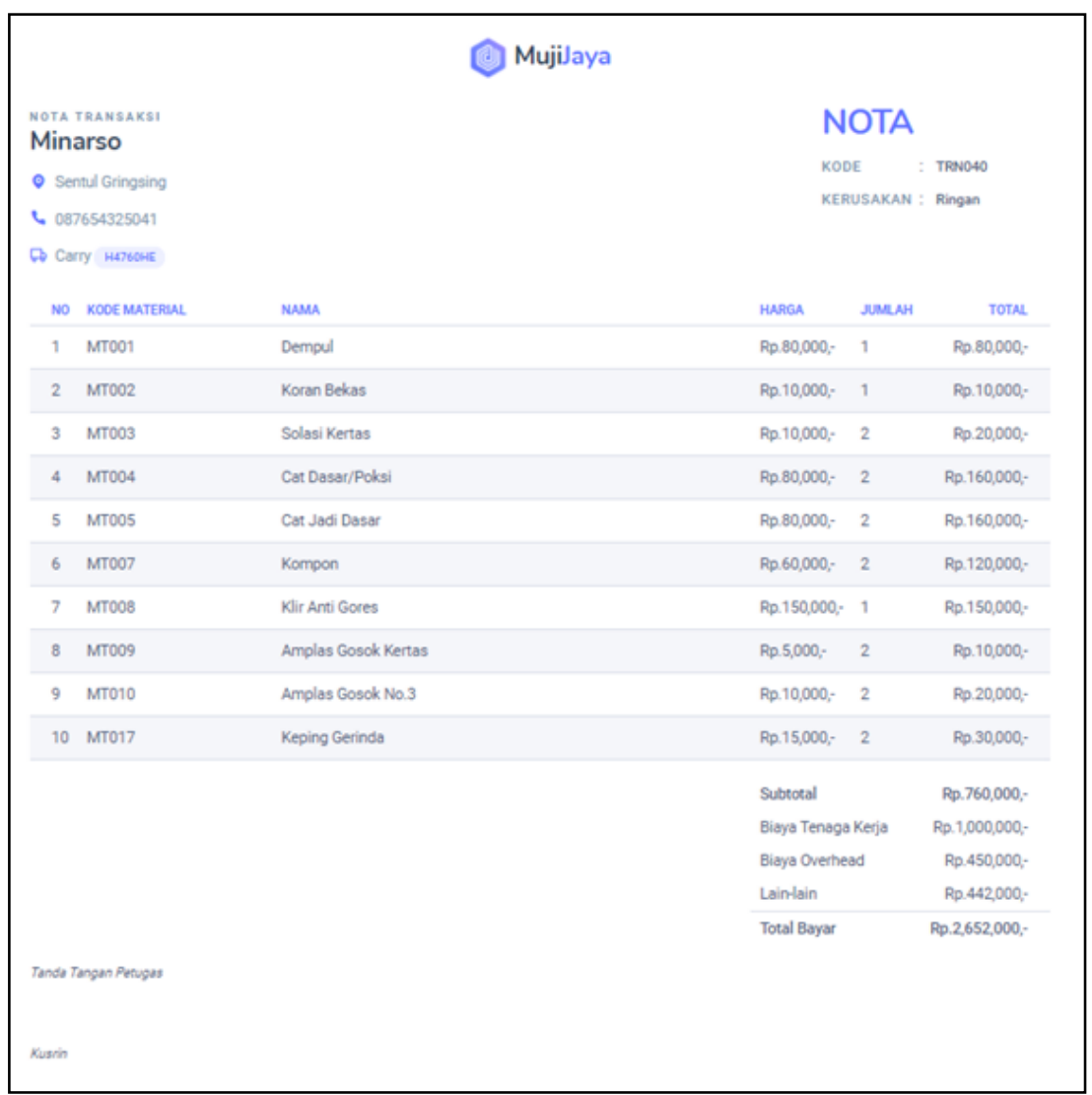

Gambar 9. Nota Penentuan Biaya

\subsection{Laporan Penentuan Biaya}

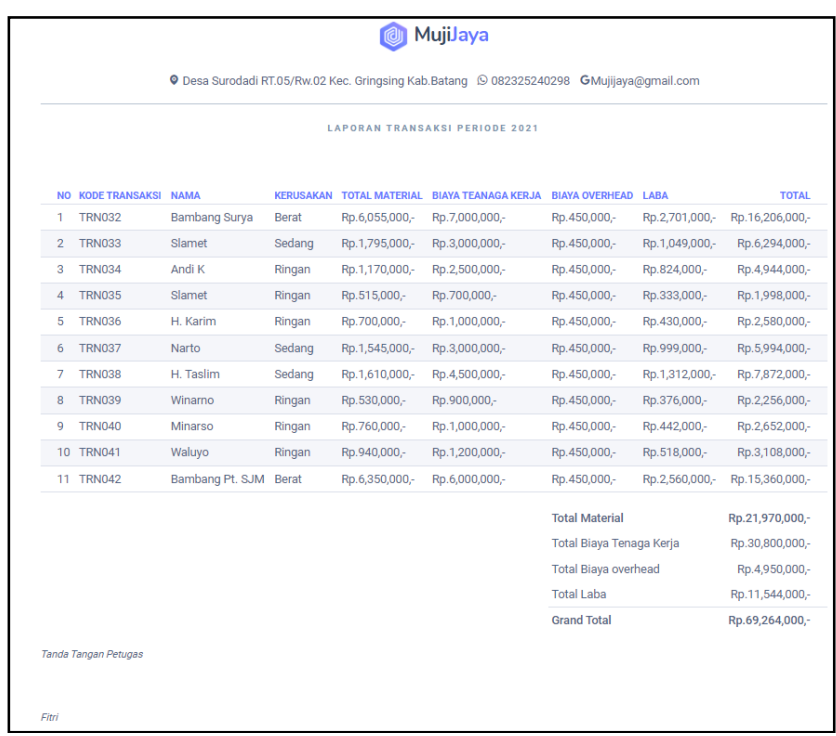

JURNAL ILMIAH MANAJEMEN DAN KEWIRAUSAHAAN Vol.1, No.2, Oktober 2021, pp. 188 - 197 
Gambar 10. Laporan Penentuan Biaya

\subsection{Laporan Laba}

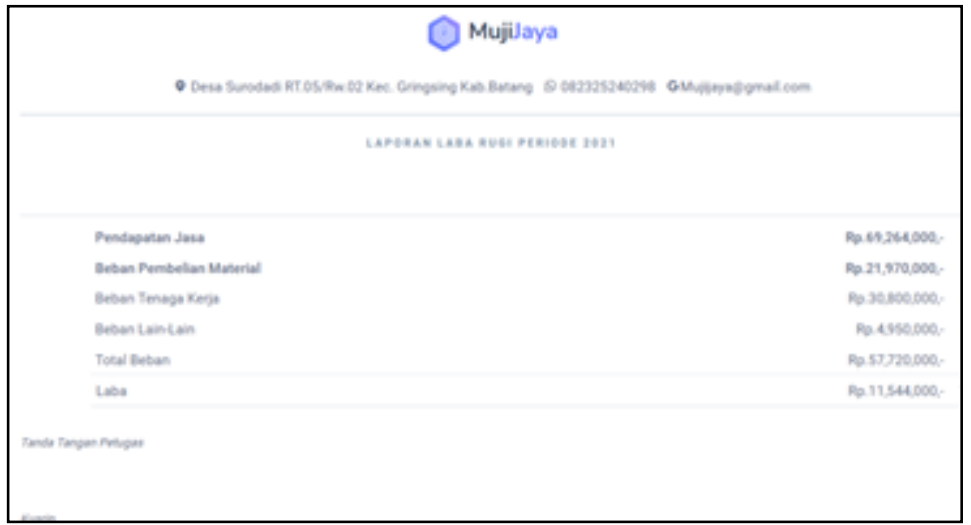

Gambar 11. Laporan Laba

\section{SIMPULAN}

Hasil penelitian implementasi pemanfaatan metode activity based costing dalam sistem informasi akuntansi penentuan biaya pada Bengkel Muji Jaya telah mencapai tujuan yang diinginkan, yaitu 1) Mampu mempermudah pengambilan keputusan penentuan biaya body repair berdasarkan semua aktivitas yang diperlukan secara cepat, tepat dan akurat.

2) Mempermudah pemilik dalam membuat dan menganalisa laporan keuangan jasa body repair secara efektif dan efisien.

\section{DAFTAR PUSTAKA}

[1] Apriani, E., \& Salesti, J. 2017. Analisa Penerapan Activity Based Costing System Dalam Menentukan Harga Pokok Produksi Project ROV's Pada PT. Oceaneering BatamMea. Measurement Vol.11 No.1 : 51-64 P-ISSN 2252-5394

[2] Pamungkas, C. A. 2017. Pengantar dan Implementasi Basis Data. Yogyakarta: Deepublish

[3] Sumarsan, T. 2018. Akuntansi Dasar dan Aplikasi Dalam Bisnis Versi IFRS. Jakarta Barat: PT Indeks

[4] Suwimayanti, N. L., \& Yudiastra, P. P. 2018. Penerapan Metode Activity Based Costing Untuk

Penentuan Harga Pokok Produksi. Jurnal Sistem dan Informatika Vol.12 No.2 : 34-44 P-ISSN 24603732

[5] TMBooks. 2015. Sistem Informasi Akuntansi - Konsep dan Penerapan. Yogyakarta: CV Andi Offset 